\title{
EFFECT OF SOME CHEMICAL INDUCERS RESISTANCE FOR CONTROLLING DOWNY MILDEW DISEASE OF GRAIN SORGHUM AND ITS IMPACT ON BIOCHEMICAL CHANGES El-Sherbeni, A.E. ; H.M.F. Awad ${ }^{2}$; A. A. Kishk ${ }^{1}$; H. M. El-Zahaby ${ }^{3}$ and A. E. A. El-Shehawy ${ }^{1}$ \\ 1 Plant Protection Dept., Fac. of Agric., Tanta Univ. \\ 2 Maize, Sugar Crops and Foliage Dis. Res. Dept., Plant Pathol. Rec. Instit., Egypt. \\ ${ }^{3}$ Agric. Bot. Dept., Fac. of Agric., Tanta Univ.
}

\begin{abstract}
Four different chemical inducers for resistance and metalaxyl fungicide were tested to control sorghum downy mildew disease (Sorghum vulgare L.) caused by Peronosclerospora sorghi (Weston and Uppal) C.G. Shaw. This evaluation was conducted at Gemmeiza Agricultural Research Station, El-Gharbea Governorate, Egypt in 2006 and 2007 seasons. Combined data reveal that metalaxyl occupied the first rank in controlling the disease. Salicylic acid was the best of the inducers in controlling sorghum downy mildew disease. While, potassium di-phosphate $\left(\mathrm{K}_{2} \mathrm{Hpo}_{4}\right)$ was the least effective one in this respect. Seedlings sprayed with salicylic acid gave the highest increase in 1000 grain weight in comparison with non-sprayed. In the same time spraying with salicylic acid and zinc sulphate increased grain sorghum leaves content of chlorophyll, nitrogen, protein and phosphorus. While potassium diphosphat increased the leaves content of chlorophyll and potassium. Iron sulphate gave the lowest values in grain sorghum leaves content. The enzymatic activity of peroxidase and polyphenoloxidase and phenolic compounds contents in the grain sorghum leaves showed the highest values with salicylic acid and potassium diphosphate followed by zinc sulphate. While iron sulphate gave the lowest values in this regard. No significant differences were obtained between metalaxl and the other compounds in the plant height and leaf area, while it showed the highest value in head length. However, metalayl followed by salicylic acid showed significant affect in increasing grain yield comparing with the other compounds. salicylic acid, potassium sulphate and metalaxyl showed highest values in increasing activities of phenols and enzymes.

Keywords : Downy mildew, Sorghum vulgare, Peronosclerospora sorghi, Metalaxyl fungicide, Salicylic acid, Potassium di-phosphate, Zinc sulphate, Iron sulphate, Peroxidase, Polyphenoloxidase, Phenolic compounds.
\end{abstract}

\section{INTRODUCTION}

Sorghum downy mildew, caused by Peronosclerospora sorghi (Weston and Uppal) C.G. Shaw, is a destructive disease of sorghum (Sorghum bicolor L.), grain sorghum (Sorghum vulgare L.) and maize (Zea mays L.). Soil-borne oospores are the major source of inoculum, and yield loss is directly related to oospores initiated infection (Frederiksen, 1980). Induced systemic resistance is a process of active resistance depending on the host plant's physical or chemical barriers activated by biotic or a biotic agents (Leeman et al., 1996 and El-Sherbeni , et al., 2008). Induced systemic resistance (ISR) stimuli were shown to be salicylic acid (De Meyer \& Hofte, 1997, Khaleifa, et al., 2007 and Mahmoud, 2007), avirulent pathogens (Kuc 
and Richmond,1977), and non-pathogens such as rhizobacteria (Wei et al.,1996). Trace elements may play an important role in protection by affecting plant susceptibility to fungal or bacterial phytopathogens ( Graham, 1983 and Abd El-Hai et al. 2007). They may also affect the predisposition of plants to viral diseases, which have been reported to increase or decrease the resistance (Graham, 1983 and Pennazio and Roggero, 1988). Treatment of cucumber lower leaves with phosphates induced systemic resistance to Colletotrichum lagenarium and reduced disease severity ( Doubravera et al., 1988). Spraying cucumber leaves with salicylic acid and ethyphone ( 2chloro ethyl phosphonic acid) reduced the disease area caused by Pseudoperonospora cubensis by more of $50 \%$ (Okuno et. al., 1991). Gamil,(1995) tested different materials as inducers against powdery mildew disease caused by Sphaerotheca faliginae, and found that acetyl salicylic acid, cobalt sulphate and di-basic potassium phosphate $\left(\mathrm{K}_{2} \mathrm{HpO}_{4}\right)$ greatly reduced powdery mildew symptoms on artificially infected plants in comparison with non treated plants.

\section{MATERIALS AND METHODS}

The present study was carried out at Gemmeiza Research Station, A.R.C. during 2006 and 2007 growing seasons.

\section{Experimental design:}

This experiment was performed in the disease nursery field prepared for evaluation against downy mildew disease. Sorghum cultivar Giza 15(as a highly susceptible) was used in this experiment which sown in plots $\left(8.0 \mathrm{~m}^{2}\right.$ in area). Each plot contain two rows with 5 meter long and $80 \mathrm{~cm}$ apart. This cultivar was obtained from the National Maize Program, Field Crops Research. The field was surrounded by three rows of the highly susceptible variety of Sudan grass ( Sordan79) as spreader which sown at least three weeks prior to planting. Three replicates were used for each inducer material in a Complete Randomized Block Design.

\section{Application of inducer materials against sorghum downy mildew:}

Four chemical compounds were used as inducers i.e. Salicylic acid, Potassium phosphate dibasic, Zinc sulphate, Iron sulphate These materials were used as spraying on sorghum leaves by three times at 7,14 , and 21 days after planting. Metalaxyl fungicide was used as a recommended check for controlling the disease. Arabic gum was added to each of the tested materials as adhesive material at concentration 1:50 ( $\mathrm{v}: \mathrm{v})$. The untreated plots (control) was sprayed with water only. Chemical structures and concentration doses are presented in Table (1).

\section{Disease assessment}

Downy mildew disease infection was recorded three times after one, two and three months of planting during the season. The infection percentage of sorghum downy mildew disease was recorded as incidence of the total plants (D.I.) using the following equation :

Disease incidence (D.I.) \% $=\frac{\text { No. of infected plants }}{\text { No. of total plants }} \times 100$ 
Efficiency percentage of the tested materials was calculated according to the equation

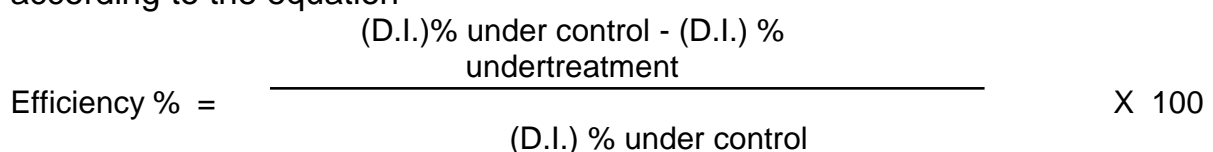

Effect of the tested materials on plant height $(\mathrm{cm})$, head length $(\mathrm{cm})$ and leaf area $\left(\mathrm{cm}^{2}\right)$ were recorded 90 days after sowing. After harvest , 1000 grain weight $(\mathrm{gm})$, and the yield/ plot were determined. Increase \% of yield/ plot as a result use of each inducer material comparing with the control treatment was calculated as follow :

$$
\text { increase } \%=\frac{\text { Yield of treated plants-yield of Control Yield }}{\text { Yield of Control }} \times 100
$$

Table (1): Chemical structure and concentration of chemical inducers.

\begin{tabular}{|c|c|c|}
\hline Chemical inducers & Chemical structure & Concentration \\
\hline & $\mathrm{oH}$ & $5 \mathrm{mM}(0.69 \mathrm{gm} / \mathrm{L})$ \\
\hline $\begin{array}{l}\text { Potassium } \\
\text { phosphate dibasic }\end{array}$ & $\mathrm{K}_{2} \mathrm{HpO}_{4}$ & $5 \mathrm{mM}(0.87 \mathrm{gm} / \mathrm{L})$ \\
\hline Zinc sulphate & $\mathrm{Zn} \mathrm{So} 4.7 \mathrm{H}_{2} \mathrm{O}$ & $5 \mathrm{mM}(1.44 \mathrm{gm} / \mathrm{L})$ \\
\hline Iron sulphate & $\mathrm{Fe} \mathrm{So} 4.7 \mathrm{H}_{2} \mathrm{O}$ & $5 \mathrm{mM}(1.39 \mathrm{gm} / \mathrm{L})$ \\
\hline $\begin{array}{l}\text { metalaxyl } \\
\text { fungicide }\end{array}$ & $\begin{array}{lrr}(\mathrm{N}-2,6-d i m e t h y l p h e n y l) & -\mathrm{N}- \\
\text { (methoxyacetyl) } \quad-\mathrm{DL}- & \text { alanine } \\
\text { methlester / dicopper } & \text { chloride- } \\
\text { trihydroxide\} } & & \\
& & \end{array}$ & $-1.5 \mathrm{gm} / \mathrm{L}$ \\
\hline
\end{tabular}

Effect of the tested inducers on chemical components of sorghum leaves:

Samples of leaves from each treatment and control plants were calculated, 55 days after sowing, in order to determine chlorophyll, nitrogen, phosphours, potassium, phenolic compound contents, and assay the activity of peroxidase and polyphenol-oxidase.

a) Determination of chlorophyll contents:

Chlorophyll a, b and a \& b were determined according to Moran and Porath (1980) using N,N-dimethyl formamide.

b) Determination of nitrogen, phosphours and potassium contents:

Leaves from each treatment and control grain sorghum were dried to constant weight. The dried leaves were grounded to fine powder. Amount of 
$0.2 \mathrm{gm}$ of the fine powder was digested using sulphuric acid and perchloeic acid (5:1 v/v, respectively) then the solution was completed to $50 \mathrm{ml}$ using distilled water. The final solution was used to determine nitrogen, phosphours and potassium content as follows:

i) Total nitrogen was determined using Kjeldahl method according to Chalmers (1984).

ii) Phosphours and potassium contents were determined using ammonium molybdate and a flame photometer method according to Chapman and Pratt (1961).

\section{c) Determination of phenolic compound :}

Samples of $5 \mathrm{gm}$ of leaves tissues were cut into small portions and immediately putted in $95 \%$ ethanol in brown bottles and kept in the dark at room temperature until the tissues were colorless then the ethanolic extracts were filtered and evaporated to near dryness on a mild water bath $60{ }^{\circ} \mathrm{C}$. The extracts were quantitatively transferred into $5 \mathrm{ml}$ of $50 \%$ isopropanol and stored in vials at $1^{\circ} \mathrm{C}$ till determination of phenolic compounds. Total and free phenols were determined using colormetric method of Folin at $250 \mathrm{~nm}$, as described by Snell and Snell (1953). Conjugated phenols were determined from subtracting free phenols from the total phenols.

d) Enzymes activity :

Peroxidase and polyphenoloxidase were determined in the extraction grain sorghum leaves, as described by Maxwell and Bateman (1967).

i) Peroxidase activity was spectrophotometriclly determined by measuring the oxidation of pyrogallol in the presence of $\mathrm{H}_{2} \mathrm{O}_{2}$ at wave length of $425 \mathrm{~nm}$, according to Allam and Hollis (1972).

ii) Polyphenoloxidase activity was determined using spectrophotometric procedure at $495 \mathrm{~nm}$, as described by Matta and Dimond (1963).

\section{Statistical analysis:}

The obtained data were subjected to analysis of variance (Steel and Torrie, 1960) Duncan's multiple rang test (DMRT) was applied for comparing means.

\section{RESULTS AND DISSCUSION}

Data in Table (2) reveal that, all of the tested compounds reduced downy mildew disease incidence (D.M.I.) comparing with the control treatment. Metalaxyl fungicide released the highest efficacy and occupied the first rank in reducing disease severity (93.04\%). Salicylic acid at $5 \mathrm{mM}$ concentration was superior in reducing the disease $(11.89 \%$ disease incidence and $80.34 \%$ Efficiency \%). Chen et al.(1997) stated that spraying salicylic acid (SA) at $5 \mathrm{mM}$ on leaves of a Lilium hybrid, stargaza, was shown to be effective in inducing resistance against Botrytis elliptica before inoculation. Audenaert et al.(1999) confermed the role of SA for the induction of induced systemic resistance in tomato to Botrytis cinerea to its effect on inducing the plant enzyme phenylalanine ammonia lyase (PAL), a key enzyme in the production of lignin and phytoalexenis. Also, SA involved in an ethelene/ jasmonic acid pathway. Achuo et al. (2004) reported that activation 
of salicylic acid dependent defense pathway via bedzothiadiazole (BTH) resulted in induced resistance against $O$. neolycopersici in tobacco but not in tomato plants.

The present work demonstrate that the level of protection induced against downy mildew varied slightly from one compound to another but significantly reduced disease incidence as compared with control treatment. Zinc sulphate followed by Iron sulphate $(5 \mathrm{mM})$ were moderate in their efficacy (67.62 and 59.25\%). While Potassium phosphate dibasic was the least one in this respect.( 45.23\%). Abd-EL Kareem (1998) found that sprayinf solutin of $\mathrm{KH}_{2} \mathrm{PO}_{4}$ at 50,100 and $150 \mathrm{mM}$ against downy mildew of cucumber reduced disease incidence by $75.8,74.2$ and $77.7 \%$, respectively. Also, Moshe, et al.(1997) stated that significantly systemic protection was obtained by $\mathrm{K}_{2} \mathrm{HPO}_{4}$ or $\mathrm{KH}_{2} \mathrm{PO}_{4}$ against powdery mildew of cucumber as well as the induced by $\mathrm{B}, \mathrm{Mn}$, and $\mathrm{Cu}$. We think that the role of metals in induction systemic induced resistance may be differed according to the disease, density of inoculums and the plant.

Slight significant effect was shown on the treated plant characters as compared with the control. Approximately, Zinc sulphate induced the most response in plant height, head length and leaf area (303.99, 21.58 and 97.44 $\mathrm{cm})$. While, the least one was induced by iron sulphate $(296.58,18.76$ and $83.35 \mathrm{~cm}$, respectively). No significant differences were found between the tested materials concerning with 1000 grain weight but it was found between them and the control treatment. Similar results were obtained by Seif ElEslam et al. (2003) who found that asprin (Acetyl salicylic acid) was the best in controlling wilt and rot-root severity of Okra and increased green pod yield compared with the check treatment. No significant differences were obtained between metalaxl and the other compounds in plant height and leaf area, while it showed the highest value in head length (24.17).

Concerning with the effect of inducers on 1000 grain weight, significance differences were detected between metalayl and the inducers compared with the control treatment. Metalayl was the first in increasing $\%$ of 1000 grain weight (\&\&), followed by salicylic acid recorded (9.02\%). Howevere, no significant was obtained between Potassium phosphate dibasic, Zinc sulphate and Iron sulphate $(6.18,6.38$ and $5.85 \%$, respectively). 
Table(2): Combined data of four chemical inducers on controlling downy mildew disease (D.M.I.), plant characters , 1000 grain weight of grain sorghum cv. Giza 15 during 2006 and 2007 growing seasons.

\begin{tabular}{|c|c|c|c|c|c|c|c|}
\hline \multirow[b]{2}{*}{ Teatments } & \multirow[b]{2}{*}{ D.M.I. \% } & \multirow[b]{2}{*}{$\underset{\%}{\text { Efficiency }}$} & \multicolumn{3}{|c|}{ Plant characters } & \multirow[b]{2}{*}{$\begin{array}{l}1000 \text { grian } \\
\text { weight (grain } \\
\text { index) gm }\end{array}$} & \multirow{2}{*}{$\begin{array}{l}\text { Increase } \\
1000 \text { grian } \\
\text { weight of } \\
\%\end{array}$} \\
\hline & & & $\begin{array}{l}\text { Plant } \\
\text { height } \\
\mathrm{cm}\end{array}$ & $\begin{array}{c}\text { Head } \\
\text { length } \\
\mathrm{cm}\end{array}$ & \begin{tabular}{|c|} 
Leaf \\
aerea \\
cm $^{2}$ \\
\end{tabular} & & \\
\hline Salicylic acid & $11.89^{\mathrm{e}}$ & 80.34 & $307.03^{\text {ab }}$ & $20.24^{\mathrm{ab}}$ & $90.46^{\mathrm{ab}}$ & $49.91^{\mathrm{a}}$ & 9.02 \\
\hline $\begin{array}{l}\text { Potassium } \\
\text { phosphate } \\
\text { dibasic }\end{array}$ & $33.11^{b}$ & 45.23 & $299.37^{a b}$ & $21.58^{a}$ & $96.98^{a}$ & 48. & 6.18 \\
\hline Zinc sulphate & $19.57^{d}$ & 67.62 & $303.99^{a b}$ & $21.38^{a}$ & $97.44^{\mathrm{a}}$ & $48.70^{a}$ & 6.38 \\
\hline Iron sulphate & $24.64^{c}$ & 59.25 & $296.58^{b}$ & $18.76^{\mathrm{bc}}$ & $83.35^{\mathrm{bc}}$ & $48.46^{a}$ & 5.85 \\
\hline Metalaxyl & $1.36^{\dagger}$ & 97.75 & $312.93^{\mathrm{a}}$ & $23.91^{\mathrm{a}}$ & $100.00^{a}$ & $50.76^{b}$ & 10.88 \\
\hline Control & $60.46^{a}$ & 0.00 & $280.81^{c}$ & $18.11^{\mathrm{c}}$ & $75.33^{c}$ & $45.78^{c}$ & 0.00 \\
\hline LSD at 0.05 & 4.66 & - & 8.73 & 1.90 & 9.20 & 1.85 & - \\
\hline
\end{tabular}

Data in Table (3) show that chlorophyll, total nitrogen, protien, phosphours and potassium contents were increased significantly as a result to spray sorghum plants with the tested materials. In general, all the previous contents were increased due to use salicylic acid except with Potassium \% . Similar results were obtained by Ismail, et al.,(2007) they stated that salicylic acid followed by $\mathrm{K}_{2} \mathrm{HPO}_{4}, \mathrm{H}_{2} \mathrm{O}_{2}$, Cobalt sulfate, and ascorbic acid decreased soybean damping off disease caused by infestation with $R$. solani,or $S$. rolfsii or $M$. phaseolina. These materials increased number and dray weight of nodules, dry weight of shoot and its $\mathrm{N}$-content and recorded the highest biological yield compared to the control. They added that seed and straw protein \% significantly increased by SA, ascorbic acid and cobalt sulfate at 75 day old. Similar results were obtained by Abd El-Hai, et al.,(2007) they tested the effect of Zinc, Ferrous, Manganese and Boron on Cowpea rust disease. They showed a significant increase in chlorophyll $a$ and $b$ content by using manganese (2 and $3 \mathrm{~g} / \mathrm{l})$, ferrous ( $3 \mathrm{~g} / \mathrm{l})$, boron $(0.025$ and $0.05 \mathrm{~g} / \mathrm{l})$ and zinc $(3 \mathrm{~g} / \mathrm{l})$ compared with other treatments. No significant differences were obtained between metalaxyl and salicylic acid concerning with the detected components.

Table(3) : Combined data of four chemical inducers on Chlorophyll, nitrogen, Protien, Phosphours and Potassium contents in leaves of susceptible cv. Giza 15, during 2006 and 2007 growing seasons.

\begin{tabular}{|c|c|c|c|c|c|c|c|}
\hline \multirow{2}{*}{ Teatments } & \multicolumn{3}{|c|}{$\begin{array}{c}\text { Chlorophyll contents } \\
\mathrm{gm} / \mathrm{dm}^{2}\end{array}$} & \multirow{2}{*}{$\begin{array}{c}\text { Total } \\
\text { nitrogen } \\
\%\end{array}$} & \multirow{2}{*}{$\begin{array}{c}\text { Protien } \\
\text { content } \\
\%\end{array}$} & \multirow{2}{*}{$\begin{array}{c}\text { Phosphours } \\
\%\end{array}$} & \multirow{2}{*}{$\begin{array}{c}\text { Potassium } \\
\%\end{array}$} \\
\hline & $\begin{array}{c}\text { Chl } \\
\text { a }\end{array}$ & $\begin{array}{c}\text { Chl } \\
\text { b }\end{array}$ & $\begin{array}{l}\text { Chl } \\
a+b\end{array}$ & & & & \\
\hline Salicylic acid & $3.79^{\mathrm{a}}$ & $0.92^{\mathrm{a}}$ & $4.71^{\mathrm{a}}$ & $3.06^{\mathrm{a}}$ & $17.60^{\mathrm{a}}$ & $0.61^{\mathrm{a}}$ & $2.72^{\mathrm{bc}}$ \\
\hline $\begin{array}{l}\text { Potassium di- } \\
\text { phosphate }\end{array}$ & $3.59^{\mathrm{ab}}$ & $0.71^{b}$ & $4.30^{\mathrm{ab}}$ & $2.51^{b c}$ & $14.43^{b c}$ & $0.57^{a}$ & $3.31^{a}$ \\
\hline Zinc sulphate & $3.28^{b}$ & $0.67^{b}$ & $3.95^{b c}$ & $3.01^{\mathrm{ab}}$ & $17.31^{\mathrm{ab}}$ & $0.58^{a}$ & $2.99^{\mathrm{ab}}$ \\
\hline Iron sulphate & $2.84^{c}$ & $0.66^{\mathrm{b}}$ & $3.50^{c}$ & $2.54^{\mathrm{bc}}$ & $14.61^{\mathrm{abc}}$ & $0.52^{\mathrm{b}}$ & $2.77^{\mathrm{bc}}$ \\
\hline Metalaxyl & $5.27^{a}$ & $1.27^{a}$ & $6.54^{a}$ & $3.48^{\mathrm{a}}$ & $20.01^{a}$ & $0.60^{a}$ & $2.92^{\mathrm{a}}$ \\
\hline Control & $1.70^{d}$ & $0.46^{c}$ & $2.16^{d}$ & $2.16^{c}$ & $12.42^{c}$ & $0.41^{c}$ & $2.46^{c}$ \\
\hline LSD at 0.05 & 0.43 & 0.16 & 0.50 & 0.53 & 3.02 & 0.05 & 0.39 \\
\hline
\end{tabular}


Data in Table (4) reveal that, the tested compounds showed some slight changes the systemic induction of total phenolic compounds as well as peroxidase and polyphenoloxidase enzymes were significantly occurred as compared with the control treatment. Spraying with Salicylic acid gave the highest values ( $8.53,3.61$ and 1.26 , respectively) followed by Potassium phosphate dibasic, $(7.82,3.03$ and 1.18 respectively), then metalayl fungicide ( $7.74,2.30$ and $0.92 \%)$. While the contrast was happened with Zinc sulphate and Iron sulphate, since it showed the least values of systemic induction. The role of chemical inducers, was explained by Raskin,(1992) who reveal that SA stimulated biosynthesis of different families of P-R proteins. While, Tilak et al.,(2002) found that it increases the activities of chitinase, peroxidase and B-1,3-glucanase .Also, Reuveni et al.,(1995) indicate that treatment with phosphate was associated with systemic resistance to different diseases. Similar results were obtained by Moshe et al.(1997). Also, Ismail et al.,(2007) stated that cobalt acid (1.00 ppm), Salicylic acid $(7.5 \mathrm{mM})$, ascorbic acid (150 $\mathrm{ppm})$ and $\mathrm{K}_{2} \mathrm{HPO}_{4}(10 \mathrm{mM})$ caused the highest activity in the peroxidase and polyphenol oxidase. Similar results were obtained by Khaleifa, et al., (2007), they found that Salicylic acid, bion, $\mathrm{FeSO}_{4}$ and $\mathrm{K}_{2} \mathrm{HPO}_{4}$ considerably increased the activity of oxidative enzymes (Peroxidase and Polyphenoloxidase) and phenolic compounds in Sesame. Metalaxyl showed lowest values in increasing activities of phenols and enzymes .

Table(4): Effect of spraying plants by four inducers on phenolic compounds and Enzymes activity in leaves of susceptible cv. Giza 15 of grain sorghum during 2006 and 2007 growing seasons.

\begin{tabular}{|l|c|c|c|c|c|}
\hline \multirow{2}{*}{ Teatments } & \multicolumn{2}{c|}{$\begin{array}{c}\text { phenolic compounds } \\
\text { mg/gm fresh weight }\end{array}$} & \multicolumn{2}{c|}{ Enzymes activity } \\
\cline { 2 - 6 } & Free & Conjugated & Total & Peroxidase & Polyphenoloxidase \\
\hline Salicylic acid & $4.84^{\mathrm{a}}$ & $3.69^{\mathrm{b}}$ & $8.53^{\mathrm{a}}$ & $3.61^{\mathrm{a}}$ & $1.26^{\mathrm{a}}$ \\
\hline $\begin{array}{l}\text { Potassium } \\
\text { phosphate dibasic }\end{array}$ & $3.36^{\mathrm{b}}$ & $4.46^{\mathrm{a}}$ & $7.82^{\mathrm{b}}$ & $3.03^{\mathrm{b}}$ & $1.18^{\mathrm{a}}$ \\
\hline Zinc sulphate & $2.30^{\mathrm{c}}$ & $3.60^{\mathrm{b}}$ & $5.90^{\mathrm{d}}$ & $2.13^{\mathrm{c}}$ & $0.68^{\mathrm{c}}$ \\
\hline Iron sulphate & $1.84^{\mathrm{d}}$ & $2.93^{\mathrm{c}}$ & $4.77^{\mathrm{e}}$ & $1.75^{\mathrm{d}}$ & $0.62^{\mathrm{c}}$ \\
\hline Metalaxyl & $3.24^{\mathrm{b}}$ & $3.68^{\mathrm{b}}$ & $6.92^{\mathrm{c}}$ & $2.29^{\mathrm{b}}$ & $0.91^{\mathrm{b}}$ \\
\hline Control & $1.64^{\mathrm{d}}$ & $1.80^{\mathrm{d}}$ & $3.44^{\mathrm{f}}$ & $1.50^{\mathrm{e}}$ & $0.47^{\mathrm{d}}$ \\
\hline LSD 0.05 & 0.43 & 0.48 & 0.34 & 0.19 & 0.10 \\
\hline
\end{tabular}

\section{REFERENCES}

Abd El-Hai, K.M. ; Abeer A. Ali ; El- Metwally, M.A. and Sahar M. El-Baz, 2007. Effect of zinc, ferrous, manganese and boron on Cowpea rust disease. J. Agric. Sci., Mansoura Univ., 32 : 9501-9510.

Abd-EL Kareem , F.I. 1998. Induction of resistance to some diseases of cucumber plants grown under greenhouse conditions. Ph. D. Thesis, Fac. of Agric. Ain Shams Univ., 117 pp. 
Achuo, E.A. ; Audenaert, K. ; Meziane, H. and Hofte, M. 2004. The salicylic acid dependent defense pathway is effective against different pathogens in tomato and tobacco. Plant Pathology, $53: 65-72$.

Allam, A.I. and Hollis, J.P. 1972. Sulfide inhibition of oxidase in rice roots . Phytopathology. $62: 634-636$

Audenaert, K ; Meyer, G-de; Hofte,M;de-Meyer,G. (1999). Pathways involved in control of Botrytis cinerea via induced resistance.Proc., $51^{\text {st }}$ international symposium on crop protection, Gent, Belgium, $64: 477$ 488.

Chalmers, R.A. 1984. Methods of Protein Analysis. Publ. ChiChester, Halsted Prrss. Addivision of John Wiley Sons., melon. Acta Phytopathology, Sinica $23: 69-73$.

Chapman, H.D. and Pratt, P.F. 1961. Methods of analysis for soils, plants and waters. University of California, Division of Agricultural Science.

Chen-ChaoYing; Huang-Hsiang,E.N.; Chen, C.Y.; and Huang, H.E. (1997). Salicylic acid- induced resistance of liliy leaves against Botrytis elliptic. Plant Pathology Bulletin, $6: 76-82$.

De Meyer, G. and Hofte, M. 1997. Salicylic acid produced by the rhizobacterium Pseudomonas aeruginosa 7NSK2 induces resistance to leaf infection by Botrytis cinerea on bean. Phytopathology 87 : 588593 .

Doubravera, N. ; Dean, R. and Kuc, J. 1988. Induction of systemic resistance to anthracnose caused by Colltotrichum lagenarium in cucumber by oxalate and extracts from spinach and rhubarb leaves. Physiological and Molecular Plant Pathology, 33 : 69-79.

El-Sherbeni , A. E.; El-Zahaby, H. M. ; Kisgk, A. A. ; Awad, H. M. F. and Aml El-Shehawy, E. A. 2008. Chemical control of downy mildew disease of grain sorghum and its impact on chemical components. The first International Conference on Environmental Studies and Research (Natural Resources \& Sustainable Development), Environmental Studies and Research Institute (ESRI), Minufiya Univ. Sadat Branch, Egypt, 7-9 April , pp. 1-9.

Frederiksen, R.A. 1980. Sorghum downy mildew in the United States : overview and outlook. Plant Disease. 64 : 903-908.

Gamil, N.A.M. 1995. Induced resistance in squash plants against powdery mildew by cobalt and phosphate sprays. Ann. Agric. Sc., Moshtohor, $33: 183-194$.

Graham, R.D. 1983. Effects of nutrient stress on susceptibility of plants to disease with particular reference to the trace elements. Advances in Botanical Research, $10: 221-276$.

Ismail, I.A. ; Nadia M. Ghalab ; Elham I. El-Khatib and Abotaleb, H.H. 2007. Influence of resistance inducers on soybean damping-off nodulation and $\mathrm{N}_{2}$ - Fixation. J. Agric. Sci., Mansoura Univ., 32 : 9189-9207.

Khaleifa, M.M. ; Abd El- Megid, M.S. and Eetmad E.I. Draz , 2007. Applying some chemical effectors for inducing systemic resistance against charcoal rot disease in Sesame. Egypt. J. of Appl. Sci., 22 : 431-446. 
Kuc, J. and Richmond, S. 1977. Aspects of the protection of cucumber against Colletotrichum lagenarium by Colletotrichum lagenarium. Phytopathology $67: 533-536$.

Leeman, M. ; Den Ouden, F.M. ; Van Pelt, J.A.; Dirkx, F.P.M. ; Steijl, H. ; Bakker, P.A.H.M. and Schippers, B. 1996. Iron availability affects induction of systemic resistance to Fusarium wilt of radish by Pseudomonas fluorescens. Phytopathology 86 : 149-155.

Mahmoud, S.M. 2007. Effect of a biotic and biotic treatments on bacterial angular leaf spot and phenolic compounds of cucumber. J. Agric. Sci., Ain Shams Univ.,Cairo. $15:$ 465- 471.

Matta, A. and Dimond, A.E. 1963. Symptoms of fusarium wilt in relation to quantity of fungus and enzyme activity in tomato stems. Phytopathology, $53: 574-578$.

Maxwell, O.P. and Bateman, D.F. 1967. Changes in the activities of some oxidases in extracts of Rhizoctonia infected bean hypocotyls. Phytopathology, $57: 132-136$.

Moran, R. and Porath, D. 1980. Chlorophyll determination in intact tissues using N,N-dimethyl for mamide. Plant Physiology. 56 : 478-479.

Moshe, R. ; Vladimir, A and Reuven, R. 1997. A foliat spray of micronutrient solutions induces local and systemic protection against powdery mildew (Sphaerotheca fuliginia) in cucumber plants. European J. of Plant Pathology $103: 581-588$.

Okuno, T. ; Nakayama, M. ; Okajima, N. and Eurusawa, I. 1991. Systemic resistance to downy mildew and appearance of acid soulbe proteins in cucumber leaves treated with biotic and a biotic inducers. Annals of the Phytopathological Society of Japan. $57: 203-211$.

Pennazio, S. and Roggero, P. 1988. Effects of trace elements on the natural resistance of asparagus bean to tobacco necrosis virus and ethylene production. Advances in Horticultural Science. 2 : 23-26.

Raskin, I., 1992. Role of salicylic acid in plant . Annu. Rev. Plant Physiology. $43: 1342-1347$.

Reuveni, M. ; Agapov,V. and Reuveni, R., 1995. Induced systemic protection to powdery mildew in cucumber by phosphate and potassium fertilizers. Effect of inculum concentration and post-inoculation treatments. Can. J. Plant Pathology, $17: 247-251$.

Seif El-Eslam, A. ; Khalil, M.N. ; Fatma S. Ahmed ; Nour Jehan M. Eisa and Khafagi, Y.S. 2003. Control methods of okra root rot and wilt disease in Egypt. Minufiya J. Agric. Res., 28 : 1793-1806.

Snell, F.D. and Snell, C.I. 1953. Colorimetric methods, Vol. III. Organic-1, DVan nostrand Company, Inc. Tronto- New York, Londn, Vol. III., P. 606.

Steel, P.G.D and Torrie, J.H. 1960. Principle and procedures of statistics. Mc Graw. Hill Nook Co. Inc., New York, 481 pp.

Tilak, P. ; Sharma, R. and Singh, B.M. 2002. Salicylic acid induced insensitivity to culture filtrate of Fusarium oxysporum f.sp. zingiberi in the calli of Zingiber officinal Roscoe. European J. of Plant Pathology. $108: 31-39$. 


\section{El-Sherbeni, A.E. et al.}

Wei, G. Klocpper, J.W. and Tuzun, S. 1996. Induced systemic resistance to cucumber diseases and increased plant growth by plant growthpromoting rhizobacteria under field conditions. Phytopathology 86 : $221-224$

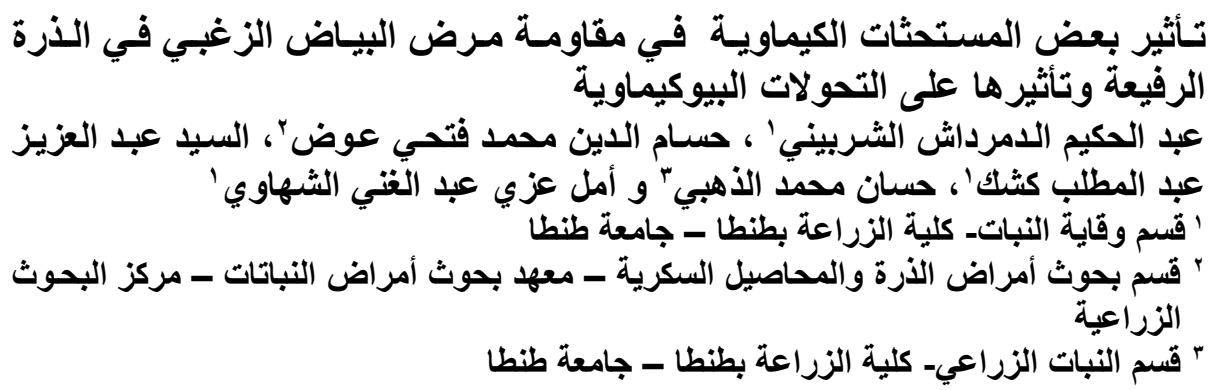

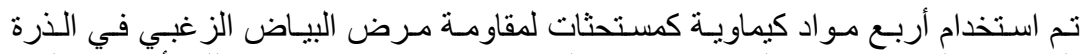

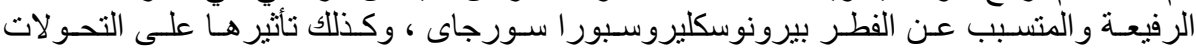

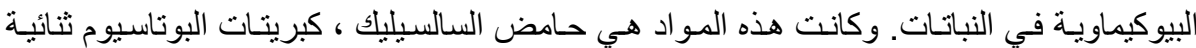

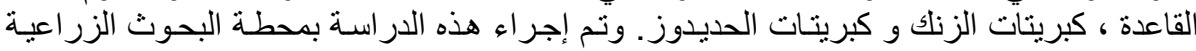

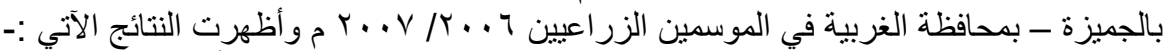

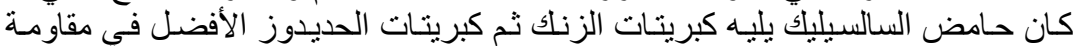



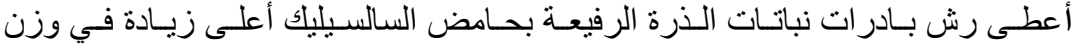

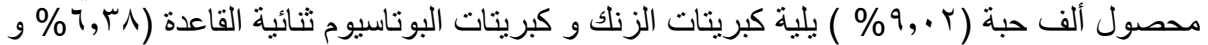

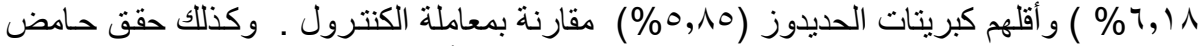

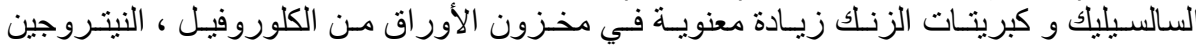

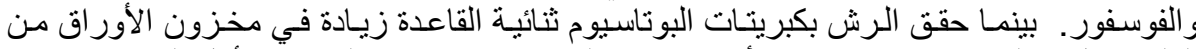

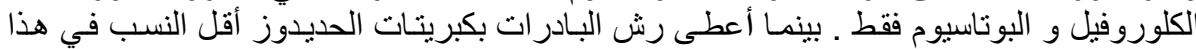

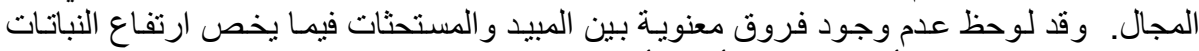

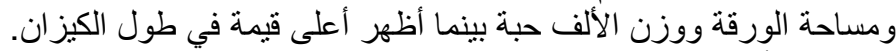

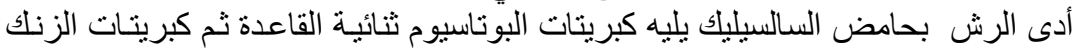

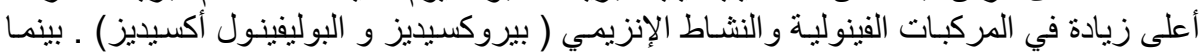
أعطى رش البادرات بكبريتات الحديدوز أقل زيادة في هذا الدجال. 